Proceedings

\title{
Benthyc Insect Larvae of Small Rivers in Central Russia (Syn- ecological Aspects) ${ }^{\dagger}$
}

\author{
Dmitry E. Vaulin, Igor E. Zykov*
}

Citation: Vaulin, D.; Zykov, I. Benthyc Insect Larvae of Small Rivers in Central Russia

(Syn-ecological Aspects), in Proceedings of the 1st International Electronic Conference on Entomology, 1-15 July 2021, MDPI: Basel, Switzerland, doi:10.3390/IECE-10370

Published: 30 June 2021

Publisher's Note: MDPI stays neutral with regard to jurisdictional claims in published maps and institutional affiliations.

Copyright: (c) 2021 by the authors. Submitted for possible open access publication under the terms and conditions of the Creative Commons Attribution (CC BY) license (http://creativecommons.org/licenses
1 State University of Humanities and Technology, Russia; dense02@gmail.com (D.E.V.); zykov-oz@yandex.ru (I.E.Z.)

* Correspondence: dense02@gmail.com

† Presented at the 1st International Electronic Conference on Entomology (IECE 2021), 1-15 July 2021; Available online: https://iece.sciforum.net/.

Abstract: Many small rivers flow in the central and northern parts of the Meshchera Lowland. Their peculiarity is bog and snow water supply, high anthropogenic impact and various overgrowing of the banks. The bottom ecosystems of these rivers include the larval stages of various insect species. The most common are representatives of the orders Diptera, Megaloptera, Odonata, Ephemeroptera, Trichoptera, Hemiptera.

The study of benthic communities showed their significant difference in insect representation and biodiversity. The communities richest in species are peculiar to the rivers and riverbed sections where the lowest ratio of dissolved organic matter to suspended matter was observed. At the same time, such communities are found not along the entire length of the river, but in spots. The collected data on various sections of the four rivers represent data on the synecology of insects with freshwater rheophilic larval stages, which make it possible to consider the benthic ecosystems of small Meshora rivers as the interaction of species and their place in detrital food webs, as well as their relationship with the areas of growth of aquatic macrophytes. The investigated bottom lotic ecosystems, including insects, can be described using the patch dynamics concept, but not the river continuum concept. This is apparently due to three factors:

1) Binding to thickets of macrophytes of food-webs.

2) Separation of environments in the ontogeny of insects. The larvae are developing in a water, and the adults live in the ground-air environment, where the reproduction process takes place. Oviposition in water takes place in convenient places with proper vegetation.

3) There is an annual restoration of ecosystems from winter shelters or refugium. That allows insects to survive during the winter in a frozen, lack of dissolved oxygen river.

Keywords: benthic macroinvertebrates; bottom ecosystems; freshwater insect larvae; patch dynamics concept

\section{Introduction}

Meshchera is a swampy and forested lowland plain formed as a result of the Dnieper glaciation about 300-250 thousand years ago. Geographically, it is located in the interfluve of the Oka, Klyazma and Moscow in the center of the European part of Russia. The sea level is height above the plain varies from 140 to $90 \mathrm{~m}$, with a decrease from north to south [1]. Many small rivers flow in the northern and central parts of the Meshchera Lowland. Their feature is the large amount of total organic matter in the water. Part of the organic matter comes from the catchment area during snow melting and rain runoff, while the other enters the rivers from the swamps feeding them [2]. These rivers are characterized by a slow current, not exceeding $0.5 \mathrm{~m} / \mathrm{s}$. Partly the banks of these rivers are overgrown with forests, in the other places the banks are meadows, 
which are flooded when the snow melts. With a relatively high population density of this area (25-50 people per square kilometer), the small Meshchera rivers usually do not flow through large cities and have a limited anthropogenic impact [3]. Due to the small size of the rivers, they are not inhabited by almost vertebrates and the variety of freshwater invertebrates is represented mainly in their ecosystems.

On this basis, natural ecosystems are compared with common theoretical concepts of river communities.

\section{Research}

We studied the inhabitants of the bottom communities of the Bolshaya Dubna, Drezna, Vokhna and Ponor rivers. These are species related mainly to the types of mollusks, annelids, arthropods. Among the latter, larval stages of insects are represented in abundance, which make up most of the species diversity of macrozoobenthos (Table 1).

Table 1. Discovered benthos species in rivers

\begin{tabular}{|c|c|c|c|}
\hline $\begin{array}{l}\text { B. Dubna } \\
\text { river }\end{array}$ & $\begin{array}{c}\text { Drezna } \\
\text { river }\end{array}$ & $\begin{array}{l}\text { Vokhna } \\
\text { river }\end{array}$ & $\begin{array}{l}\text { Ponor } \\
\text { river }\end{array}$ \\
\hline \multicolumn{4}{|c|}{ Insecta } \\
\hline $\begin{array}{l}\text { Calopterix splendens, Cordu- } \\
\text { lia aenea, Gomphus vulgatis- }\end{array}$ & $\begin{array}{l}\text { Calopterix splendens, } \\
\text { Gomphus vulgatissimus }\end{array}$ & $\begin{array}{l}\text { Calopterix splendens, } \\
\text { Cordulia aenea }\end{array}$ & - \\
\hline \multicolumn{4}{|c|}{ Ephemeroptera } \\
\hline $\begin{array}{l}\text { Baetis bioculatus, Leptophle- } \\
\text { bia marginata, Heptagenia } \\
\text { flava, Heptagenia sulfurea, } \\
\text { Ephemera vulgata }\end{array}$ & $\begin{array}{l}\text { Baetis bioculatus, Lepto- } \\
\text { phlebia marginata, Hepta- } \\
\text { genia flava, Ephemera vul- } \\
\text { gata }\end{array}$ & $\begin{array}{l}\text { Ecdyonurus fluminum, } \\
\text { Baetis bioculatus }\end{array}$ & - \\
\hline \multicolumn{4}{|c|}{ Trichoptera } \\
\hline $\begin{array}{l}\text { Hydropsyche ornatula, Mo- } \\
\text { lanna angustata, Semblis } \\
\text { phalaenoides, Limnephilus } \\
\text { flavicornis, Anabolia nervosa, } \\
\text { Anabolia furcate, Stenophylax } \\
\text { stellatus, Triaenodes bicolor, } \\
\text { Phryganea striata, Halesus } \\
\text { Interpunctatus, Potamophylax } \\
\text { latipennis }\end{array}$ & $\begin{array}{l}\text { Molanna angustata, Semblis } \\
\text { phalaenoides, Stenophylax } \\
\text { stellatus, Anabolia nervosa, } \\
\text { Triaenodes bicolor, Po- } \\
\text { tamophylax latipennis }\end{array}$ & $\begin{array}{l}\text { Molanna angustata, } \\
\text { Athripsodes aterrimus }\end{array}$ & - \\
\hline \multicolumn{4}{|c|}{ Megaloptera } \\
\hline Sialis lutaria & Sialis lutaria & Sialis lutaria & Sialis lutaria \\
\hline \multicolumn{4}{|c|}{$\underline{\text { Hemiptera }}$} \\
\hline Corixa dentipes & Corixa dentipes & - & - \\
\hline \multicolumn{4}{|c|}{ Diptera } \\
\hline $\begin{array}{l}\text { Chironomidae sp., Tabanus } \\
\text { bovinus, Dicranota bimacula- } \\
\text { ta, Pedicia rivosa }\end{array}$ & $\begin{array}{l}\text { Chironomidae sp., } \mathrm{Di}- \\
\text { cranota bimaculata }\end{array}$ & Chironomidae sp. & Chironomidae sp. \\
\hline \multicolumn{4}{|c|}{ Coleoptera } \\
\hline Agabus bipustulatus & - & - & - \\
\hline \multicolumn{4}{|c|}{ Other taxons } \\
\hline $\begin{array}{l}\text { Tubifex tubifex, Herpobdella } \\
\text { octoculata, Piscicola geometra }\end{array}$ & $\begin{array}{l}\text { Tubifex tubifex, Piscicola } \\
\text { geometra }\end{array}$ & $\begin{array}{l}\text { Tubifex tubifex, } \\
\text { Herpobdella octoculata, } \\
\text { Piscicola geometra }\end{array}$ & Tubifex tubifex \\
\hline \multicolumn{4}{|c|}{ Mollusca } \\
\hline $\begin{array}{l}\text { Sphaeriidae sp., Bithinia sp., } \\
\text { Anisus contortus, Lymnaea } \\
\text { sp. }\end{array}$ & $\begin{array}{l}\text { Pisidium amnicum, Bithyn- } \\
\text { ia tentaculata, Anisus con- } \\
\text { tortus, Lymnaea sp. }\end{array}$ & $\begin{array}{l}\text { Pisidium amnicum, } \\
\text { Unio pictorum, Bithynia } \\
\text { sp., Anisus contortus, } \\
\text { Lymnaea sp. }\end{array}$ & - \\
\hline \multicolumn{4}{|c|}{ Arthropoda } \\
\hline
\end{tabular}


The greatest number of individuals and species of benthos was found in the thickets of macrophytes and adjacent areas of the bottom. At the same time, on some sections, the diversity of species was reduced. For example, during a survey on the Drezna River (code of the state water register of the Russian Federation 09010300612110000031581) in August 2019, 47 Asellus aquaticus, 5 Hydrachna geographica, only 2 Sialis lutaria, a small number of gastropods were found at site No. 2. At the same time, a noticeably higher diversity was observed at site No. 1 upstream in the same period (Table 2). The depletion of benthic communities is also accompanied by a significant increase in water turbidity arising from a field close to the coast, mowed for agricultural purposes. Thus, the determination of the water transparency by the Snellen's font at section No. 1 gave a value of $20-23 \mathrm{~cm}$, and at section No. 2 only 11. In addition, a significant amount of large suspended particles of detritus was determined by examining the water under a microscope and visually, and their size reached $1 \mathrm{~mm}$. When filtering water, the remainder of suspended organic matter amounted to $21 \mathrm{mg}$ of dry weight per liter of water.

Table 2. The difference in the discovered biodiversity at two points of the Drezna river (quantity by species for August 2019)

\begin{tabular}{ll}
\hline \multicolumn{1}{c}{ site No. 1} & \multicolumn{1}{c}{ site No. 2} \\
\hline Tubifex tubifex - 22, Piscicola geometra -3, & Tubifex tubifex - 14, Bithynia tentaculata - 1, \\
Sphaeriidae sp - 17, Bithynia tentaculata -5, & Lymnaea sp. - 2, Asellus aquaticus -47, Chi- \\
Anisus contortus - 1, Lymnaea sp. - 5, Asellus & ronomidae sp. - 11, Corixa dentipes - 1, Sialis \\
aquaticus - 12, Calopterix splendens - 1, & lutaria - 2, Hydrachna geographica - 5 \\
Gomphus vulgatissimus - 1, Baetis bioculatus & \\
- 2, Leptophlebia marginata - 7, Heptagenia & \\
flava - 3, Ephemera vulgate - 2, Molanna an- & \\
gustata - 3, Semblis phalaenoides - 1, Steno- & \\
phylax stellatus - 3, Anabolia nervosa - 4, Tri- \\
aenodes bicolor - 5, Potamophylax latipennis - \\
2, Sialis lutaria - 7, Chironomidae sp. - 17, \\
Dicranota bimaculata - 1
\end{tabular}

A similar picture was observed on the Ponor River (code of the state water register of the Russian Federation 09010101812110000024287). This small river flows through a very swampy area, has muddy and grassy shores, and in the area of the village of Novoye, large organic particles from mowing also get into the water.

The greatest diversity was found at section No. 1 and No. 2 of the Malaya Dubna River and section No. 1 of the Drezna River. There are the following types of insects:

The attachment of benthic communities to macrophyte thickets was observed in all cases. At the same time, predatory species belonging to the order Odonata, as well as burrowing forms of predatory insect larvae of the orders Diptera, Ephemeroptera, are numerous in the same place.

\section{Discussion}

Based on the revealed ecological features of the formation of benthic communities and the larval stages of insects represented in them, we formulate the following suppositions:

1) Spatially localized food chains originating from macrophytes. The important role of higher aquatic plants as producers for benthic systems is well studied and understood [4]. However, the localization of communities in them can hardly be explained by the food source alone. Many active predators and detritus feeders are not directly attached to 
food plants [5]. Nevertheless, these species are also observed in greater numbers in places where aquatic plants grow, with distance from which the probability of detecting individuals sharply decreases.

2) Probably the second important factor in the distribution of insects along the bottom is the peculiarity of their ontogeny. It proceeds at different stages in different environments. The larvae develop in water, and the adults live in the ground-air environment, where the reproduction process takes place. Eggs are laid in water in convenient places with characteristic vegetation. Eggs are laid directly in water or on aquatic plants so that the hatched larva is in the aquatic environment [6].

For example, the found representatives of the genus Sialis (Megaloptera) lay eggs on plants above the water surface [7]. The larva hatched from them falls into the water, passively reaching the environment required for development. Nymphs of the genus Sialis are inactive; they lead a burrowing way of life or hide in the mud. Thus, they do not move away from the plants on which they hatched. Representatives of the suborder $\mathrm{Zy}$ goptera (Odonata) also use macrophytes when laying eggs. So the females of the families Calopterygidae and Lestidae lay eggs directly in the stems of plants [8]. In this case, both the surface parts of the plant and the underwater ones are used. The insect, moving along the stem and introducing eggs into it, is completely immersed in water. The larvae of these dragonflies swim well, but passive hunting is characteristic of them [9]. They do not pursue prey, but wait sitting on aquatic plants. Thus, they also do not move away from their place of birth. The larvae of the family Coenagrionidae adhere to a similar strategy. The eggs of the females of this family also lay on macrophytes, only on the surface of plants under water. It is associated with macrophytes and oviposition by caddisflies (Trichoptera) or representatives of the family Tabanidae (Diptera). The same can be said about representatives of other orders and genera of insects present in the rivers. These developmental features also determine the attachment of animals to aquatic macrophytes.

3) Small rivers Meshchera have a shallow depth, usually 0.5-1.0 m. The climate of the region is sharply continental; winters in the region are cold. Average temperatures in January are $-11^{\circ} \mathrm{C}$. Severe frosts last up to 30 days a year. The recorded absolute minimum temperature is $-52^{\circ} \mathrm{C}$. In such a climate, small rivers in some years freeze almost to the bottom. In the released layer of water during thawing or in the ground, insect larvae can find food only in the form of dead parts of aquatic plants. Such plant residues accumulate in places of their usual seasonal growth. There are refugia of detritivores. Predators are also concentrated there. Thus, the life of insects in early spring is also tied to the habitats of aquatic plants. Ecosystems are restored annually from winter shelters or refugia.

We assume that all of the factors above jointly determine the binding of macrozoobenthos to macrophyte thickets.

\section{Theoretical significance}

The features revealed in the study of the zoobenthos of small rivers are of theoretical importance for hydroecology [10]. At present, attempts have been made in the ecology of inland waters to describe the regularities of the functioning of river ecosystems [11]. The proposed schemes are called concepts. The most famous of them are the river continuum concept [12], the patch dynamics concept [13], the nutrient spiraling concept [14], and the network dynamics hypothesis [15]. The ability to predict the type and species composition of river ecosystems based on a general concept is of interest. The applicability of such concepts for the small rivers of Meshchera can be assessed on the basis of the studies carried out. The rivers of the 1-2 orders described by us flow through the swampy area and have a significant input of organic matter from the catchment area. There is no significant change in ecosystems during their course. 
The distribution of the spots abundantly populated by aquatic organisms seems to be random. This makes the application of most of the proposed concepts unreasonable. On the other hand, the concept of spot dynamics describes well the observed distribution of zoobenthos. In accordance with it, the organization of river ecosystems is formed under the influence of temporary factors, both random and seasonally changing. This is precisely the conclusion that our studies have led. Unfortunately, this significantly limits the ability to predict the detection of a species at a specific location.

\section{References}

1. Diakonov, K. N.; Abramova, T. A. Itogi paleolandshaphtnyh issledovaniy v Centralnoy Meshchere. Izvestia russkogo geographicheskogo obschestva (Bulletin of the Russian Geographical Society) 1998. Volume 130 № 4; pp. 10-21. (in Russian)

2. Ahmetieva, N. P.; Mihailova, A. V.; Krichivetsh, G. N. Vliyanie gidrologicheskogo rejima torfyanikov Meshcherskoy nizmennosty na rejim bolotnyh rek. Trudy Instorfa (Proceedings of Peat institute) 2020. № 22 (75), pp. 3-11. (in Russian)

3. Zykov, I. E.; Vaulin, D. E. Sravnitelnyy analiz bioticheskikh indeksov ocenki kachestva vody reki Bolshaya Dubna vostochnogo Podmoskovya [A comparative analysis of the biotic indexes of water quality assessment of the river Large Dubna Moscow region]. Ekologicheskiy vestnik [Ecological Bulletin], Minsk, 2015. № 4 (34); pp. 121-125. (in Russian)

4. Siu Yeon Tan, Zhu Li, Shuiping Cheng Ecological interaction between submerged macrophytes and zoobenthos. SDRP Journal of Earth Science and Environmental Studies 2017. Volume 2, Issue 2, pp. 173-182.

5. Andrew J. Bohonak, David G. Jenkins Ecological and evolutionary significance of dispersal by freshwater invertebrates. Ecology Letters 2003. Volume 6, Issue 8, pp. 786-793. https://doi.org/10.1046/j.1461-0248.2003.00486.x

6. Pavlovskiy, E. H.; Lepnyova, S. G. Ocherki is zhizni presnovodnyh zhivotnyh Publisher: Soviet Science, Moscow, USSR 1948. pp. 376-380. (in Russian)

7. Thorp, J. H.; Rogers, D. C. Thorp and Covich's Freshwater Invertebrates, 4th Edition, Publisher: Academic Press, 2015. pp. 1059-1072. https://doi.org/10.1016/B978-0-12-385026-3.09001-X.

8. Onishko, V. V.; Kosterin, O. E. Dragonflies of Russia. Illustrated Photo Guide Publisher: Phiton XXI, Moskow, Russia, 2021. pp. 40-72 (in Russian)

9. Plavilschikov, N. N. Zhizn pruda. Publisher: Detgiz, Moscow, USSR, 1952. pp. 42-46 (in Russian)

10. Malmqvist, B. Aquatic invertebrates in riverine landscapes Freshwater biology 2002. Volume 47, Issue 4, pp. 679-694

11. Thorp, J. H. et all. Riverine macrosystems ecology: sensitivity, resistance, and resilience of whole river basins with human alterations Frontiers in Ecology and the Environment 2014. Volume 12, Issue 1, pp. 48-58. https://doi.org/10.1890/120367

12. Vannote, R. L. et all. The River Continuum Concept Canadian Journal of Fisheries and Aquatic Sciences 1980. Volume 37, Number 1, pp. 130-137. https://doi.org/10.1139/f80-017

13. Townsend, C. R. The Patch Dynamics Concept of Stream Community Ecology North American Benthological Society 1989. Volume 8, Number 1, pp. 521-544. https://doi.org/10.2307/1467400

14. Newbold, J. D. et all. Measuring Nutrient Spiralling in Streams Canadian Journal of Fisheries and Aquatic Sciences 1981. Volume 38(7) pp. 860-863. https://doi.org/10.1139/f81-114

15. Benda, L. et all The Network Dynamics Hypothesis: How Channel Networks Structure Riverine Habitats BioScience 2004. Volume 54, Issue 5, pp. 413-427, https://doi.org/10.1641/0006-3568(2004)054[0413:TNDHHC]2.0.CO;2 